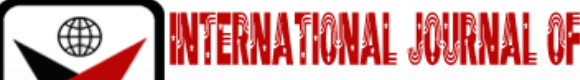

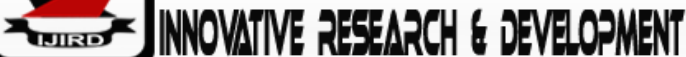

ISSN 2278-0211 (Online)

\section{The Effect of Banking Performance, Insurance Institutions and Capital Market toward Economic Growth in Indonesia}

\author{
Toto Rusmanto \\ Associate Professor, Department of Accounting, \\ Bina Nusantara University, Jakarta, Indonesia \\ Aloisia Rosa Amelia \\ Student, Department of Accounting, Bina Nusantara University, \\ Jakarta, Indonesia
}

\begin{abstract}
:
The economic growth is affected by many factors. This study will investigate whether the three factors including banking performance, insurance institutions performance, and capital markets in a country will affect its economic growth. The study took place in Indonesia. The study applied a quantitative method, and used secondary data sources with a documentation data collection technique. The population of this study is banking companies and insurance institutions listed on the Indonesia Stock Exchange (IDX) for the year 2017-2019 with purposive sampling technique, the analytical method using IBM SPSS Statistics Base 23.0. The research findings indicate that the three factors including Return on Assets on bank, Non-Performing Loan on bank, Return on Assets on insurance company, banking and insurance stock returns on IDX have non-significant effects on economic growth in Indonesia.
\end{abstract}

Keywords: Banking performance, insurance institution, stock market performance, economic growth

\section{Introduction}

The role of financial institutions in economic growth is an interesting field to study. The important role of the financial sector in real economic growth has been confirmed by many researchers both at the international and national levels (Seven \&Yetkiner, 2015). Banks have a very crucial role in supporting economic growth in a country, because banks are institutions that collect funds sourced from the community with excess funds and provide credit to the public with a shortage of funds (Hasibuan, 2011). Banks are financial institutions that have a major contribution in increasing GDP in Indonesia. In addition, the non-bank financial industry is very diverse and quite large in supporting economic activities in a country and in providing funding to the public or companies that need funds $(0 J \mathrm{~K}, 2018)$. The Indonesian capital market, which is part of the development of the financial sector, also contributes to economic growth. The capital market is a market where there are buying and selling transactions of long-term financial instruments, such as equities (stocks), debt securities (bonds), mutual funds, and other instruments.

The COVID-19 outbreak that occurred around the world raised concerns and predictions by the International Monetary Fund and the World Bank proved to be entering the second quarter of 2020. Economic growth declined during the crisis period (both the global financial crisis and the local banking crisis), which highlighted the importance of a banking system resilient during crisis periods. In response to the period of crisis and recession that occurred in Indonesia in the last 3 quarters, the role of insurance as protection against losses is very significant. In addition, in Indonesia, the stock market experienced various increases and decreases, especially when entering the era of the COVID-19 pandemic. Thus, this study was conducted to determine whether there is a significant effect between the performance of banks, insurance institutions, and stock returns, especially banking and insurance, with the rate of economic growth in Indonesia.

A stable financial sector is one of the five main components that influence economic growth, the other four being structural transformation, inequality, lack of investment by the government, and political motives (Stiglitz, 2016). The results of research conducted by Rachdi\&Hassene (2011), state that development in the financial sector has a positive effect and is closely related to real GDP, so that in an effort to maintain sustainable economic growth, a country must improve the performance of the financial sector and take important steps. in an effort to strengthen the relationship between the real sector and the financial sector. This is in line with the facts found by Zhuang et al. (2019), which finds consistent evidence that bank efficiency has a positive effect on regional economic growth. Insurance as a risk transfer mechanism, contributes greatly to the economic growth of a country by encouraging long-term investment through capital collected from the accumulation of individual deposits. Based on research conducted by Pant \& KC (2017), it shows that insurance contributes to economic growth that encourages individuals to invest and manage risk in an efficient way. 
Investors need a strategy in determining their investment, so the nature and direction of causality between stock market developments and economic growth are important for investors, and can also have important policy implications. The results of research conducted by Jannah (2019) show that in the long term the Islamic stock market has no effect on economic growth but has an effect on economic growth in the short term. Therefore, a study was conducted on these three factors, namely the performance of banking, insurance, and capital markets to find empirical evidence on their influence on the rate of economic growth in Indonesia for the period 2017-2019.

In this study, it is hoped that the results can provide benefits to readers, both Organizations, Companies, Individuals are expected to provide benefits for readers to understand in more detail the impact of the performance of financial institutions, namely banking institutions and insurance institutions as well as the stock market on the Indonesian economy as reference material, guidelines, considerations, additional information, or comparisons for further research as well as for customers and investors are expected to be information and material for consideration in making investment decisions.

\section{Literature Review}

This section will discuss regarding the literature and hypothesis development of some factors that can affect economic growth as follows. The function of financial institutions is to facilitate trade, facilitate risk management, mobilize resources, obtain and process information and allocate capital (Kierkegaard, 2020). The contribution of financial institutions in general to economic growth according to Kierkegaard (2020) is as follows: (i) Increase trade and flows of goods and service. (ii) Increase the level of capital accumulation. (iii) Increase efficiency in combining capital and labor in production.

Bank is one of the profit-oriented service companies so that it must maintain its financial performance well, especially on its profitability performance. Bank profitability is one aspect that can be used as a benchmark to assess the success of a bank in carrying out its operations. Bank profitability is the bank's ability to generate profits (Sudiyatno, 2013). The performance indicator or bank performance is measured by Return on Assets (ROA) based on the consideration that ROA includes the ability of all elements of bank assets used to earn income. In accordance with the Circular Letter of Bank Indonesia No.6/23/DPNP concerning the Rating System for Commercial Bank Soundness dated May 31, 2004, it is recognized that ROA is used as a proxy for profitability in banking companies. Return on Assets (ROA) is a ratio used to measure management's ability to earn a total profit where the greater the ROA, the greater the level of profit achieved by the company and the better the rating of the company in using assets (Rinati, 2012).

The fact that an unstable financial sector negatively affects sustainable economic growth (Owusu\&Odhiambo, 2014) is in line with the findings of Stiglitz (2016) that a stable financial sector is one of the five main components that affect economic growth, the other four being structural transformations, inequality, lack of investment by the government, and political motives. Zhuang et al. (2019), found consistent evidence that bank efficiency has a positive effect on regional economic growth. In addition, the results of research by Klein \& Weill (2018) support the view that bank profitability increases economic growth that occurs in the short term. The results of research conducted by Setiawan (2020) show that Islamic bank financing and conventional bank credit significantly affect economic growth. Financing and increasing credit have a positive effect on economic growth. The effect of change is inelastic, not very large, but the effect is significant.

A stable financial sector is one of the five main components that influence economic growth, the other four being structural transformation, inequality, lack of investment by the government, and political motives (Stiglitz, 2016). This is in line with the fact that an unstable financial sector negatively affects sustainable economic growth (Owusu\&Odhiambo, 2014). Zhuang et al. (2019), found consistent evidence that bank efficiency has a positive effect on regional economic growth. In addition, the results of research by Klein \& Weill (2018) support the view that bank profitability increases economic growth that occurs in the short term. The results of research conducted by Setiawan (2020) show that Islamic bank financing and conventional bank credit significantly affect economic growth. Financing and increasing credit have a positive effect on economic growth. The effect of change is inelastic, not very large, but the effect is significant. Based on this description, the following hypothesis is obtained:

- H1: Bank performance has a significant effect on the rate of economic growth in Indonesia.

Based on research conducted by Pant \& KC (2017), it shows that insurance contributes to economic growth that encourages individuals to invest and manage risk in an efficient way. Insurance as a risk transfer mechanism, contributes greatly to the economic growth of a country by encouraging long-term investment through capital collected from the accumulation of individual deposits

Insurance as a risk transfer mechanism, contributes greatly to the economic growth of a country by encouraging long-term investment through capital collected from the accumulation of individual deposits. Based on research conducted by Pant \& KC (2017), it shows that insurance contributes to economic growth that encourages individuals to invest and manage risk in an efficient way. There is a statistically significant positive relationship between insurance sales and economic growth in some parts of Europe based on a study conducted by Peleckiene et al. (2019). However, this relationship varies in different countries due to differences in income levels so that the influence of insurance developments on a country's economic growth is not direct because it depends on the investment performance of insurance companies (Lee et al., 2018). The results of research by Mainata\&Pratiwi (2019), show that the variable growth of Islamic insurance has an influence on economic growth in Indonesia. Based on this description, the following hypothesis is obtained:

- H2: The performance of insurance institutions has a significant effect on the rate of economic growth in Indonesia.

The capital market is a means of funding for companies and other institutions as well as a means for investing activities. One of the capital market instruments is the stock which is the most important and popular capital market instrument. According to Hamilton (1922), shares are a form of security that shows the holder has proportional ownership 
in a company. Transactions of buying and selling shares occur on the stock exchange, although there are also private sales (Jeremy J. Siegel, Jeremy J., 2008).

Financial-Market-Based Economies are economies with a financial system that relies primarily on financial markets for credit allocation. Compared to bank-based systems, companies rely more on direct financing through financial markets and investors allocate more of their savings to investment than bank deposits (Greenspan, 2020). Go Public is a series of processes from a private company to a public company by selling and offering some of its shares to the public, then listing its shares on the Indonesia Stock Exchange (IDX, 2020).

The stock market is the main source for any company to raise funds for business expansion and plays an important role in the growth of industry and trade in any country. Through the primary stock exchange market, companies can issue shares to the public and obtain funds for business purposes. To issue shares to investors, a company must be listed on a stock exchange. The secondary function of an exchange is to provide a liquidity platform for buyers and sellers of shares listed on the stock market. In the secondary market of the stock exchange, both retail and institutional investors buy and sell shares (Kumar, 2014).

Investors need a strategy in determining their investment, so the nature and direction of causality between stock market developments and economic growth are important for investors and can also have important policy implications. A study conducted by Kajurová\&Rozmahel (2016), shows that the long-term effect of economic growth on stock market development is detected in several member countries of the European region. In addition, there is a shortterm reciprocal relationship between growth and the stock market. In non-European countries, only the short-term impact of stock market developments on economic growth was found. Stock market performance is usually considered as a reference for economic growth and stock returns as well as economic growth. Empirical results show that co-movement stock returns and economic growth are relatively strong but fluctuate in the United States and relatively weak but stable in China (Jiang, 2019). The results of research conducted by Jannah (2019) show that in the long term the Islamic stock market has no effect on economic growth but has an effect on economic growth in the short term. Based on this description, the following hypothesis is obtained:

- H3: Banking and insurance stock returns have no significant effect on the rate of economic growth in Indonesia.

\section{Methodology}

The units of analysis in this study are banking companies and insurance institutions in Indonesia listed on the Indonesia Stock Exchange and shares of banking and insurance companies listed on the Indonesia Stock Exchange in 20172019 quarterly. The object of research in this study is the performance of banking, the performance of insurance institutions, and stock returns of banking and insurance companies. This research is quantitative and uses secondary data in its processing. The data used are data sourced from the company's quarterly financial statements for 2017 to 2019 . In addition, data sourced from IDX Quarterly Statistics is used every quarter from 2017 to 2019, Official Statistics News every quarter, books, journals, websites internet and other trusted media related to this research. In this study, the population is all banking companies and insurance institutions in Indonesia listed on the Indonesia Stock Exchange for the period 20172019. The sampling method that will be used is purposive sampling. The criteria in the sampling method of this study are banking companies and insurance institutions in Indonesia that are registered and have published quarterly financial reports for the period 2017-2019, present their financial statements using the rupiah exchange rate (Rp), and the company has completed and available data for research.

Furthermore, in preparing this research, the sample collection method used is the documentation method from the financial statements of banking companies and insurance institutions in Indonesia that have been registered and published by the Indonesia Stock Exchange (IDX) during the 2017-2019 period and the stock prices of listed banking and insurance companies on the Indonesia Stock Exchange. The statistical analysis method used is statistical software IBM SPSS Statistics Base 23.0. In this study, there are three independent variables, namely bank performance, insurance institution performance, and banking and insurance stock returns and one dependent variable, namely the rate of economic growth in Indonesia. In this study, Indonesia's GDP growth rate by business field is used as an indicator of the rate of economic growth, and bank performance indicators are measured by Return on Assets (ROA) and Non-Performing Loans (NPL), insurance performance is measured by Return on Assets (ROA), and Capital market performance is measured by stock returns of banking and insurance companies.

In this study, statistical tests were used, namely descriptive statistical tests, classical assumption tests in the form of normality tests with the One-Sample Kolmogorov-Smirnov Test, multicollinearity tests, autocorrelation tests with Run Tests, and heteroscedasticity tests, as well as hypothesis testing using multiple regression analysis in the form of tests, coefficient of determination, $\mathrm{t}$ test, and $\mathrm{F}$ test. The method used in analyzing the variables in this study is to use multiple linear regression because this study has four independent variables. The mathematical equations used in the first study are as follows:

$$
Y=a+\beta_{1} X_{1}+\beta_{2} X_{2}+\beta_{3} X_{3}+\beta_{4} X_{4}+\varepsilon
$$

where:

$\mathrm{Y}=$ Economic Growth

$a=$ Constant

$\beta_{1}-\beta_{4}=$ Regression Coefficient

$X_{1}=$ Return on Assets Bank

$X_{2}=$ Non-Performing Loan Bank 
$X_{3}=$ Return on Assets Asuransi

$X_{4}=$ Return Saham Perbankan dan Asuransi

$\varepsilon=$ Error

The objects needed in this research are banking companies and insurance companies. To be selected as a research sample, banking companies must meet the sample criteria. The population in this study amounted to 43 for banking companies and 15 for insurance companies so that 15 companies were obtained as samples with 10 banking companies and 5 insurance companies. So, the amount of data during the 2017-2019 quarterly period, which is for 12 periods, is 480 data including banking and insurance stock return data for 12 periods. With a total of 480 data, the data used is the mean data for each quarter period. This is because the data on the rate of economic growth obtained is quarterly data.

\begin{tabular}{|l|c|r|r|r|r|r|r|}
\hline & $\mathrm{N}$ & Range & Minimum & Maximum & \multicolumn{1}{c|}{ Sum } & Mean & Std. Deviation \\
\hline ROAB & 12 & .0031 & .0196 & .0227 & .2468 & .020567 & .0008648 \\
NPLB & 12 & .0026 & .0229 & .0255 & .2901 & .024175 & .0008593 \\
ROAI & 12 & .0337 & .0085 & .0422 & .2481 & .020675 & .0100243 \\
RETURN & 12 & .3207 & -.0967 & .2240 & .1445 & .012039 & .0952215 \\
EGROW & 12 & .0030 & .0497 & .0527 & .6106 & .050883 & .0009183 \\
Valid N (listwise) & 12 & & & & & & \\
\hline
\end{tabular}

Table 1: Descriptive Statistics

The number of observations is the number of periods, namely 2017-2019 per quarter. Based on the results of the descriptive statistical research above, some information can be obtained as follows:

- The Bank's Return on Assets (ROAB) has a minimum value of $1.96 \%$, a maximum value of $2.27 \%$, a mean value of $2.06 \%$, and a standard deviation of $0.09 \%$. Based on data from the Financial Services Authority (2016), Return on Assets in banking is said to be normal if it exceeds $1.5 \%$, so that the overall sample of banking companies obtained is already generating profits and managing their assets optimally as indicated by an average ROA of $2.06 \%$.

- Non-Performing Loan Bank (NPLB) has a minimum value of $2.29 \%$, a maximum value of $2.55 \%$, a mean value of $2.42 \%$, and a standard deviation of $0.09 \%$. This indicates that the average bank is in a healthy condition with an average NPL of less than $5 \%$.

- Return on Assets Insurance (ROAI) has a minimum value of $0.85 \%$, a maximum value of $4.22 \%$, a mean value of $2.07 \%$, and a standard deviation of $1.00 \%$. Overall, the sample of insurance companies obtained is already generating profits and managing their assets optimally as indicated by an average ROA of $2.07 \%$.

- The Banking and Insurance Stock Return (RETURN) has a minimum value of $-9.67 \%$, a maximum value of $22.40 \%$, a mean value of $1.20 \%$, and a standard deviation of $9.52 \%$. With an average of $1.20 \%$, this shows that the shares of the banking and insurance sectors in the 2017-2019 period received a positive return.

- The Economic Growth Rate (EGROW) has a minimum value of 4.97\%, a maximum value of 5.27\%, a mean value of $5.09 \%$, and a standard deviation of $0.09 \%$. With an average of $5.09 \%$, this shows that the rate of economic growth in Indonesia in the 2017-2019 period is stable.

\subsection{Basic Assumption Test}

The basic assumption test aims to determine whether the estimation model does not have serious deviations from the assumptions that have been made. There will be a condition if it fulfills some classical assumptions such as normality, there is no perfect multicollinearity between independent variables, there is no autocorrelation and there is no heteroscedasticity. 


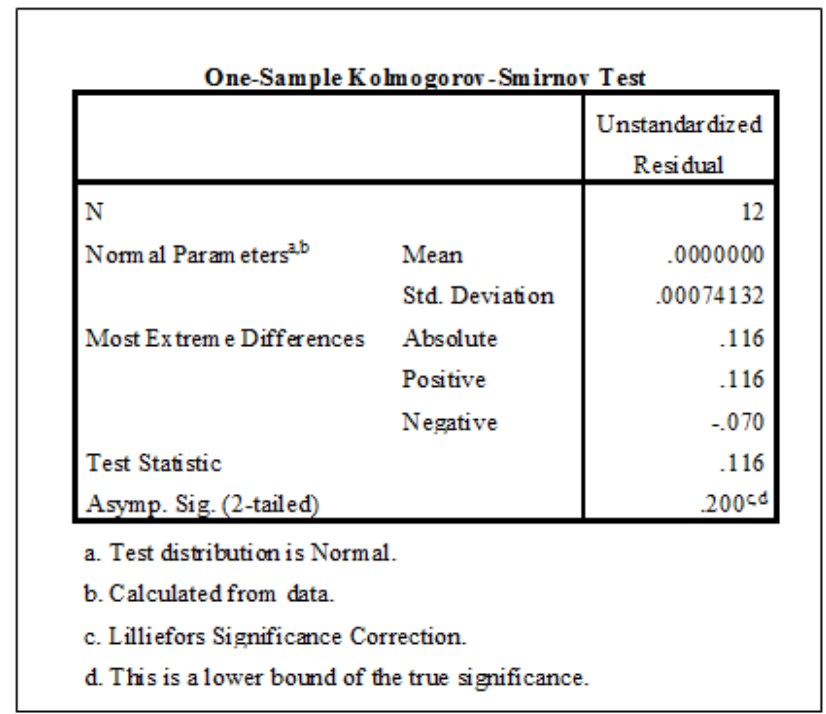

Table2: Normality Test

Based on Table 2 The results of the calculation of the One-Sample Kolmogorov-Smirnov Test obtained a statistical test result of 0.116 with a significance level of 0.200 . With this significance value, the residual value of the observation data is normally distributed because it produces a significance value greater than 0.05 or $5 \%$.

\begin{tabular}{|c|c|c|c|c|c|c|c|}
\hline \multicolumn{8}{|c|}{ Coefficients $^{\mathrm{a}}$} \\
\hline \multirow[t]{2}{*}{ Model } & \multicolumn{2}{|c|}{$\begin{array}{c}\text { Unstandardized } \\
\text { Coefficients }\end{array}$} & \multirow{2}{*}{$\begin{array}{c}\text { Standardized } \\
\text { Coefficients } \\
\text { Beta } \\
\end{array}$} & \multirow[t]{2}{*}{$\mathrm{t}$} & \multirow[t]{2}{*}{ Sig. } & \multicolumn{2}{|c|}{$\begin{array}{c}\text { Collinearity } \\
\text { Statistics }\end{array}$} \\
\hline & B & Std. Error & & & & Tolerance & VIF \\
\hline 1 (Constant) & .038 & .015 & & 2.453 & .044 & & \\
\hline ROAB & .485 & .411 & .457 & 1.180 & .276 & .621 & 1.611 \\
\hline NPLB & .135 & .457 & .126 & .296 & .776 & .509 & 1.966 \\
\hline ROAI & -.001 & .037 & -.007 & -.017 & .987 & .567 & 1.764 \\
\hline RETURN & -.005 & .005 & -.548 & -1.155 & .286 & .413 & 2.420 \\
\hline
\end{tabular}

Table 3: Multicollinearity Test

If the Tolerance value is more than 0.1 and the VIF value is less than 10 , then there is no multicollinearity between the independent variables, and vice versa. The results of the Tolerance value from the multicollinearity test that have been carried out show the values of $0.621,0.509,0.567$, and 0.413 with values greater than 0.1 . The results of the VIF value from the multicollinearity test that has been carried out show the values of 1,611,1,966, 1,764, and 2,420 with values less than 10 . So, it can be concluded that there is no intercorrelation among the independent variables and is free from multicollinearity problems.

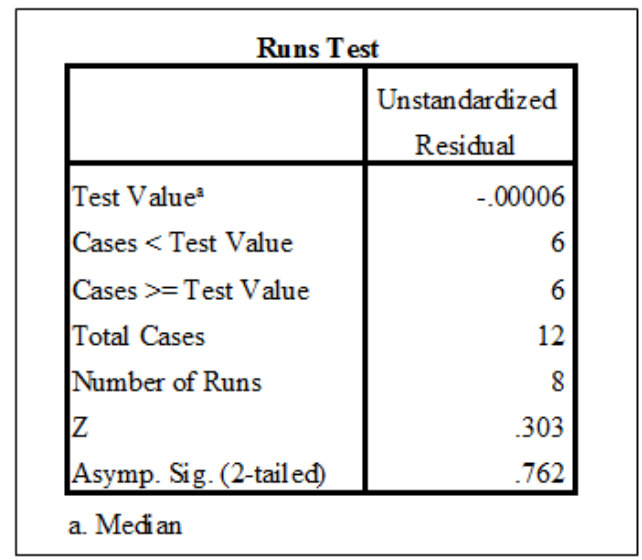

Table 4 Run Test

Based on the results of the Run Test that has been carried out above, the Asymp value is generated. Sig. (2tailed) with a value of 0.762 where the basis for decision making in the Run Test Asim is the Asymp value. Sig. (2-tailed) is less than $0.05(<0.05)$ then there is an autocorrelation symptom and vice versa. So, it can be concluded that there is no autocorrelation symptom because the value of the Run Test Asim results is above 0.05 with a value of 0.762 . 


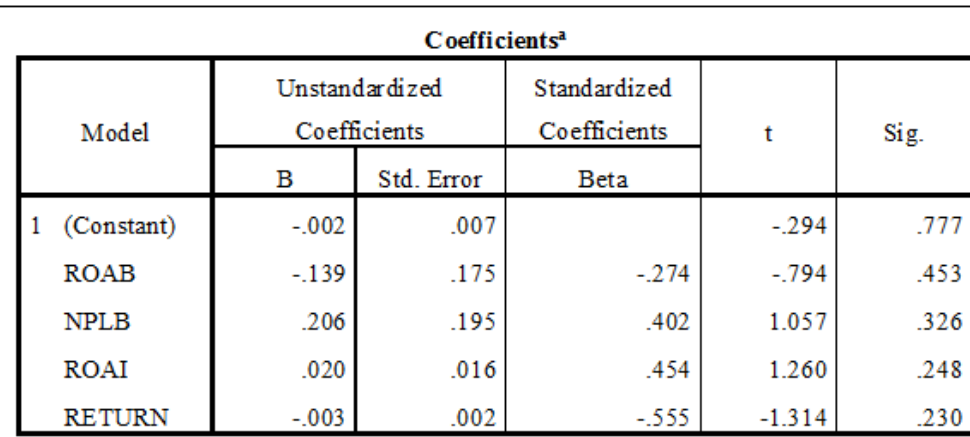

a. Dependent Variable: Abs_RES

Table5: Heteroskedasticity Test

The basis for decision making in the Glejser test in detecting heteroscedasticity is if the significance value of Sig. greater than $0.05(>0.05)$ then there is no symptom of heteroscedasticity in the regression model and vice versa. The test results based on the table above are the Bank's ROA variable with a significance value of 0.453, Bank's NPL with a value of 0.326 , Insurance ROA with a value of 0.248 , and Stock Return of banking and insurance with a value of 0.230 . So, it can be concluded, there is no symptom of heteroscedasticity because the value of the Glejser test results for the four independent variables is greater than 0.05 so that the test can be continued to the next step.

\subsection{Hypothesis Testing}

Hypothesis testing was conducted to determine the effect of the performance of banking companies, the performance of insurance institutions, and the stock returns of banking and insurance on the rate of economic growth in Indonesia. Hypothesis testing is done by using multiple linear regression method (multiple regression).

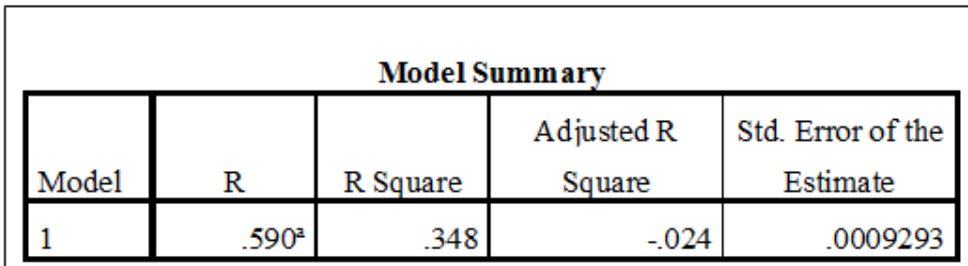

a. Predictors: (Constant), RETURN, ROAB, ROAI, NPLB

Table 6: Determination Coefficient $\left(R^{2}\right)$

Based on Table 6 the $\mathrm{R}$ value obtained from the coefficient of determination test is 0.590 which indicates that the $\mathrm{R}$ value is greater than 0.5 . This shows that the performance variables of banking companies as measured in ROA and NPL, the performance of insurance institutions as measured in ROA, and banking and insurance stock returns have a strong correlation with the dependent variable, namely the rate of economic growth, because it has an $\mathrm{R}$ value between $0.50-0.75$. In addition, the Adjusted R Square value is 0.348 which indicates that $34.8 \%$ of the dependent variable in this study, namely the rate of economic growth can be explained by the existing independent variables, namely the performance of banking companies as measured in ROA and NPL, the performance of insurance institutions as measured in ROA, and stock returns in banking and insurance. While the remaining $65.2 \%$ is explained by other variables outside the research model.

\begin{tabular}{|l|}
\begin{tabular}{|l|r|r|r|r|r|}
\hline Model & Sum of Squares & \multicolumn{1}{|c|}{ df } & Mean Square & F & Sig. \\
\hline 1 Regression & .000 & 4 & .000 & .935 & $.496^{\mathrm{b}}$ \\
Residual & .000 & 7 & .000 & & \\
Total & .000 & 11 & & & \\
\hline
\end{tabular} \\
a. Dependent Variable: EGROW \\
b. Predictors: (Constant), RETURN, ROAB, ROAI, NPLB \\
\hline
\end{tabular}

Table 7: F Test

\section{Result and Discussion}

Based on the results of the ANOVA or F test in Table 7 above, the calculated $\mathrm{F}$ value is 0.935 with a significance level of 0.496 or greater than 0.05 . The results showed that the ROA of the bank, the bank's NPL, the ROA of insurance, and 
the return of banking and insurance stocks simultaneously had no significant effect on the rate of economic growth and in other words the regression model could not be used to predict the rate of economic growth in Indonesia.

\begin{tabular}{|c|c|c|c|c|c|c|}
\hline \multicolumn{7}{|c|}{ Coefficient $s^{\mathrm{a}}$} \\
\hline \multirow{2}{*}{\multicolumn{2}{|c|}{ Model }} & \multicolumn{2}{|c|}{$\begin{array}{c}\text { Unstandardized } \\
\text { Coefficients }\end{array}$} & \multirow{2}{*}{$\begin{array}{c}\text { Standardized } \\
\text { Coefficients }\end{array}$} & \multirow[t]{2}{*}{$\mathrm{t}$} & \multirow[t]{2}{*}{ Sig. } \\
\hline & & B & Std. Error & & & \\
\hline & (Constant) & .038 & .015 & & 2.453 & .044 \\
\hline & ROAB & .485 & .411 & .457 & 1.180 & .276 \\
\hline & NPLB & .135 & .457 & .126 & .296 & .776 \\
\hline & ROAI & -.001 & .037 & -.007 & -.017 & .987 \\
\hline & RETURN & -.005 & .005 & -.548 & -1.155 & .286 \\
\hline
\end{tabular}

Table 8: $t$ Test

The individual parameter significance test or $\mathrm{t}$ statistical test is used to show how far the influence of the independent variables individually (individually) in explaining the variation of the dependent variable. The significance value used in the $t$ test is $=5 \%$. The criteria for testing the hypothesis using the $t$ statistical test is that if the significance value is $<0.05$, then an independent variable individually and significantly affects the dependent variable. Based on the test results from Table 9 above, the regression equation in this study was obtained, namely:

\section{$E G R O W=0.038+0.485 R O A B+0.135 N P L B-0.001 R O A I-0.005 R E T U R N$}

Return on Assets (ROA) measures a bank's ability to earn earnings from its operations. ROA is used as an indicator of bank performance or performance based on the consideration that ROA includes the ability of all elements of bank assets used to earn income. The results of data processing using SPSS 23 software, obtained Beta (B) results of 0.485 and a significance value of 0.276 on the basis of decision making if the significance value is above 0.05 , then partially ROA of the bank does not significantly affect the rate of economic growth and has a positive direction so that reject the hypothesis H1. Non-Performing Loan (NPL) shows the ability of bank management in managing loans provided by banks. The results of data processing using SPSS 23 software, obtained the coefficient of determination of 0.135 and a significance value of 0.776 on the basis of decision making if the significance value is above 0.05 then partially, the bank's NPL has no significant effect on the rate of economic growth and has a positive direction so that it rejects the hypothesis. H1.

The results of this study support the results of research conducted by Zhuang et al. (2019) which finds consistent evidence that bank efficiency has a positive effect on regional economic growth. In addition, there is research conducted by Klein \& Weill (2018) which supports two views, namely that bank profitability increases economic growth and bank profitability in the past had an insignificant effect and only lasted in the short term. Based on previous research, it is stated that bank profitability has a positive but not significant effect on the rate of economic growth because ROA and NPL are not the only determinants of banking performance and based on this research, regional banks with different economic policies are conducted. However, the results of this study do not support the results of research from Setiawan (2020), indicating that conventional bank credit and Islamic bank financing significantly affect economic growth. Increased credit and financing have a positive effect on economic growth. The change effect is not very large, not elastic, but the effect is significant.

Return on Assets (ROA) is used as an indicator of the performance of insurance institutions based on the consideration that ROA covers the ability of all elements of insurance institutions' assets to generate income. The results of data processing using SPSS 23 software, obtained the coefficient of determination of -0.001 and a significance value of 0.987 with the basis of decision making if the significance value is above 0.05 then partially, the ROA of insurance institutions has no significant effect on the rate of economic growth and has a positive direction so that reject hypothesis $\mathrm{H} 2$.

The results of this study support the results of research conducted by Pant \& KC (2017), showing that insurance contributes to economic growth that encourages individuals to invest and manage risk in an efficient manner. The results of research by Mainata\&Pratiwi (2019), show that the variable growth of Islamic insurance has an influence on economic growth in Indonesia but the effect is not significant. Based on research by Lee et al. (2018) the relationship varies in various countries due to differences in income levels so that the influence of insurance developments on a country's economic growth is not direct because it depends on the investment performance of insurance companies. However, the results of this study do not support the results of the study of Peleckiene et al. (2019) where there is a statistically significant positive relationship between insurance sales and economic growth in some parts of Europe. In addition, the study by Lee et al. (2016) finds that the relationship between life insurance and economic growth is negative in regimes with relatively unhealthy institutional environments. This is due to differences in insurance institutional conditions that have the potential to hinder the growth of the insurance sector and can be explained by other macroeconomic problems.

Stock returns or stock returns are the results obtained from stock investments. Financial sector stocks based on the Jakarta Stock Industrial Classification (JASICA) measure the performance of all shares of companies that provide financial services such as banks, consumer finance institutions, venture capital, investment services, insurance, and holding companies. The results of data processing using SPSS 23 software, obtained the coefficient of determination of - 
0.005 and a significance value of 0.286 with the basis of decision making if the significance value is above 0.05 then partially, banking and insurance stock returns have no significant effect on the rate of economic growth and have a direction negative so that it accepts hypothesis H3.

The results of this study support the results of research conducted by Jannah (2019), showing that the Islamic stock market has no effect on economic growth in the long term but has an effect on economic growth in the short term. In addition, there is research by Kajurová \& Rozmahel (2016), which shows that the long-term effect of economic growth on stock market development is detected in several member countries of the European region. However, the results of this study do not support the results of research from Jiang (2019), the empirical results show that the co-movement of stock returns and economic growth is relatively strong but fluctuating in the United States and relatively weak but stable in China.

\section{Conclusions}

Based on the phenomena, problem formulation, discussion of hypotheses and the results of data analysis that have been tested from the research, it is concluded that the performance of banking companies as measured by Return on Assets and Non-Performing Loans has a positive and insignificant effect on the rate of economic growth, the performance of insurance institutions that measured by Return on Assets has a negative and insignificant effect on the rate of economic growth, the stock returns of banking and insurance have a negative and insignificant effect on the rate of economic growth, as well as the performance of banking companies, the performance of insurance institutions, and the stock returns of banking and insurance together. the same (simultaneously) has no significant effect on the rate of economic growth.

In implementing the sampling method in this study, it means that not all populations of banking and insurance companies are used as research objects, thus creating a sampling risk, namely the selected sample cannot represent the population so that the conclusions in this study cannot be generalized to actual events, that is one of the limitations of study. For further research, it is expected to use additional measuring variables that project the performance of banks and the performance of other insurance institutions in addition to Return on Assets which is already widely used and it is recommended to increase the number of research samples and add years to the research period

\section{References}

i. Hasibuan, M. (2011). Dasar-dasarPerbankan. Jakarta: BumiAksara.

ii. Jannah, B. (2019). Kontribusi PasarSaham SyariahTerhadap Pertumbuhan Ekonomi Indonesia. Jurnal PenelitianIlmu Ekonomi WIGA, 9(2). 78-86.

iii. Jiang, Y. (2019). Dynamics in the co-movement of economic growth and stock return: comparison between the United States and China. Economic Research-Ekonomska Istraživanja, 32(1), 1965-1976.

iv. Kajurová, V. \&Rozmahel, P. (2016). Stock market development and economic growth: Evidence from the European Union. ActaUniversitatisAgriculturaeetSilviculturaeMendelianaeBrunensis, 64(6), 1927-1936.

v. Klein, P. O., \& Weill, L. (2018). Bank profitability and economic growth. BOFIT Discussion Papers, 15.

vi. Lee, H. S., Yong, Z. J., \& Lim, X. M. (2018). Insurance development and economic growth. Financial Statistical Journal, 1(2).

vii. Mainata, D., \&Pratiwi, A. (2019). Pengaruh Pertumbuhan Asuransi Syariahterhadap Pertumbuhan Ekonomi Indonesia. International Journal Ihya' 'Ulum Al-Din, 21(1), 56.

viii. OtoritasJasaKeuangan. (2018). Buku Statistik Perasuransian 2017. Jakarta: OtoritasJasaKeuangan.

ix. Pant, S., \& KC, F. B. (2017). Contribution of insurance in economic growth of Nepal. Journal of Advanced Academic Research, 4(1). 99-110.

x. Peleckienė, V., Peleckis, K., Dudzevičiūtė, G., \&Peleckis, K. (2019). The relationship between insurance and economic growth: evidence from the European Union countries. Economic Research-EkonomskaIstraživanja, 32(1), 1138-1151.

xi. Rachdi, H. \&Hassene B. (2011). The Causality between Financial Development and Economic Growth: Panel Data Cointegration and GMM System Approaches .International Journal of Economics and Finance, 3(1), 143151.

xii. Setiawan, I. (2020). AnalisisPeranPerbankanterhadapPertumbuhanEkonomi di Indonesia: Bank Syariah Versus Bank Konvensional. JurnalAkuntansi, EkonomidanManajemenBisnis, 8(1), 52-60.

xiii. Seven, U. \&Yetkiner, H. (2015). Financial intermediation and economic growth: Does income matter?Economic Systems, 40(1), 1-20.

xiv. Stiglitz, J. E. (2016). How to restore equitable and sustainable economic growth in the United States. American Economic Review, 106(5), 43-47.

xv. Zhuang, H., Yin, H., Wang, M., \& Yang, J. (2019). Bank efficiency and regional economic growth: Evidence from China. Annals of Economics and Finance, 20(2), 661-689. 